\title{
PERKEMBANGAN PENDIDIKAN ISLAM DI BRUNEI DARUSSALAM
}

\begin{abstract}
Oleh: Suddin Bani*
ABSTRACT: Borneo Darussalam is one of the countries in the world claims itself as Islamic country that follows the Syafi'e school in Figh and Asy'ariyah in Theology. The history of Islam comes to Borneo Darussalam has some versions like another Asian countries. One version said that Islam came to Borneo in the 7 centuries and another version said that in the 13-14 centuries which was brought by Arabian Trade. Educational model in Borneo is the same in Singapore and Malaysia with the pattern A-7-3-2-2 by using Malay and English instruction with focusing on the priority of human's morality to get religion and master technology. The government (Kingdom) has paid more attention to educational progress. The is shown to the educational budget portion is too high and the position of education is very high to society's view.
\end{abstract}

KEYWORDS: Islam, pendidikan, dan madrasah

ISLAM dalam perkembangannya mengalami kemajuan yang cukup signifikan, meskipun pada negara tertentu mengalami pluktuasi, bahkan ada yang hampir punah seperti di Spanyol. Penyebaran Islam terjadi dengan beberapa cara. Di antaranya adalah orang-orang Islam pergi ke suatu daerah/negara dengan tujuan dakwah. Selain itu, ada juga dengan tujuan berdagang tetapi mendakwakan Islam sebagai agama. Kemudian dalam berdakwah dan berdagang mereka juga melakukan perkawinan, dan yang lebih menarik karena mereka mengawini anak bangsawan, penguasa dan lain sebagainya.

Sejarah masuk dan berkembangnya Islam di Asia Tenggara di kalangan sejarawan, khususnya aspek kebudayaan, masih belum tersingkap secara sempurna. Menurut Azyumardi Azra hal ini disebabkan antara lain karena kajian sejarah Islam dengan berbagai aspeknya di Asia Tenggara, baik oleh kalangan asing maupun pribumi belum mampu merumuskan

*Magister Agama lulusan Program Pascasarjana UIN Alauddin Makassar, Konsentrasi Pendidikan Islam yang saat ini sedang mengikuti program Doktor pada Universitas yang sama, adalah dosen Fakultas Tarbiyah dan Keguruan Universitas Islam Negeri Alauddin Makassar. 
suatu paradigma historis yang dapat dijadikan pegangan bersama yang kadang-kadang sulit dipertemukan satu sama lain. ${ }^{1}$

Brunei Darussalam yang menjadi fokus dalam pembahasan ini merupakan salah satu negara kecil di Asia Tenggara jika dibandingkan dengan negara tetangganya, Malaysia dan Indonesia. Sebelum membicarakan lebih jauh tentang perkembangan pendidikan di negara tersebut, terlebih dahulu diuraikan perkembangan Islam sebagai bagian yang tak terpisahkan dalam pembahasan tentang perkembangan pendidikan di negara yang dimaksud. Satu hal yang menarik bahwa Brunei Darussalam adalah negara yang agak eksklusif/tertutup dengan dunia luar, sehingga kajian-kajian tentang Brunei Darussalam dalam beberapa aspek agak sulit ditemukan. Hal ini mungkin disebabkan karena ia merupakan negara yang sudah makmur.

\section{SEJARAH SINGKAT BRUNEI DARUSSALAM}

Secara georafis Brunei Darussalam terletak di pulau Kalimantan, tepatnya di pantai Barat Laut Kalimantan. Bagian Baratnya merupakan dataran pantai yang berawa sedangkan bagian Timur berbukit. Nama resminya adalah Brunei Darussalam (Negara yang penuh kedamaian). Ibu kotanya adalah Bandar Sri Begawan. Luas wilayahnya lebih kurang 5.765 $\mathrm{km}$ persegi. Titik tertinggi adalah bukit Pagon $(1850 \mathrm{~m})$ dan sungai utama adalah sungai Belait. Brunei terbagi atas empat distrik yaitu: Distrik Brunei, Distrik Tutong, Distrik Belait, dan Distrik Temburong. ${ }^{2}$ Ia termasuk dalam negara rumpun Melayu. Brunei dianggap sebagai negara tua di antara kerajaan-kerajaan di tanah Melayu. Keberadaan Brunei Tua diperoleh berdasarkan catatan Arab, China, dan tradisi lisan. Dalam catatan sejarah China dikenal dengan nama Po-li, Po-lo, Poni atau Puni dan dalam catatan Arab dikenal dengan istilah Dzabaj atau Ranjd. ${ }^{3}$ Mueflich Hasbullah dalam mengutip pendapat Sharon mengatakan bahwa kerajaan Islam Melayu menyerukan kepada masyarakat untuk setia kepada rajanya, melaksanakan Islam dan menjadikannya sebagai jalan hidup serta menjalani kehidupan dengan mematuhi segala karakteristik dan sifat bangsa Melayu sejati Brunei Darussalam, termasuk menjadikan bahasa Melayu sebagai bahasa utama. ${ }^{4}$

Brunei zaman dahulu disebut kerajaan Borneo kemudian berubah menjadi Brunei. Nama Borneo ini diduga kuat disandarkan kepada Borneo sebagai nama lain dari pulau Kalimantan karena Brunei terletak di bagian Barat Laut Kalimantan. Versi lain mengatakan Brunei berasal dari kata baru nah yang dalam sejarah dikatakan bahwa pada awalnya ada rombongan Klan atau suku Sakai yang dipimpin oleh Pateh Berbai pergi ke Sungai Brunei mencari tempat untuk mendirikan negeri baru. Setelah mendapat- 
kan kawasan tersebut yang memiliki kedudukan sangat strategis karena diapit oleh bukit dan air dan mudah untuk dikenal serta untuk transfortasi dan kaya akan ikan sebagai sumber pangan yang banyak di sungai, merekapun mengucapkan perkataan baru nah artinya tempat itu sangat baik, berkenan, dan sesuai di hati mereka untuk mendirikan negeri seperti yang mereka inginkan. Kemudian percatan Baru Nah itu lama kelamaan berubah menjadi Brunei. Klan atau Sakai yang disebutkan tadi ádalah serombongan pedagang dari China yang gemar berniaga dari satu tempat ke tempat lain. Itulah sebabnya konon pada awalnya kerajaan Brunei merupakan pusat perdagangan orang-orang China. ${ }^{5}$

Di antara negara-negara rumpun Melayu, Brunei Darussalam termasuk yang termuda karena baru diproklamirkan sebagai negara merdeka pada tanggal 1 Januari 1984 dengan pernyataan sebagai berikut:

...bahwa mulai 1 Januari 1984 negara Brunei Darussalam ádalah dan dengan izin Allah Subhanahu Wa Taala akan untuk selama-lamanya kekal menjadi sebuah negara Melayu Islam Berraja yang merdeka. Berdaulat dan demakratik bersendikan ajaran-ajaran Islam menurut Ahli Sunnah Wal Jamaah. ${ }^{6}$

Pernyataan di atas menyatakan secara resmi bahwa Brunei Darussalam merupakan negara yang bersendikan ajaran-ajaran "ahlu al sunnah wal jamaah". Di samping itu mazhab Syafi'i ditetapkan sebagai mazhab resmi negara dalam perlembagaan negara. Bahkan didapatkan informasi bahwa telah ditetapkan jauh sebelumnya yaitu sejak raja ke 24, Sultan Abdul Momin (1852-1885), sedangkan mazhab lain dianggap sebagai kegiatan akademik saja. Dengan demikian, maka Brunei Darussalam merupakan satu-satunya negara di dunia yang menetapkan dasar negara, tidak hanya Islam tetapi juga Ahlussunnah Wal Jamaah bermazhab Syafi'i. Islam masuk ke Brunei pada masa raja ke-5, Sultan Bolkiah (1485-1524) setelah jatuhnya Malaka ke tangan Portugis.7

Sebagian ahli sejarah mengatakan bahwa Brunei telah ada setidaknya sejak abad ke-7 atau ke-8 M. Kerajaan ini kemudian ditaklukkan oleh Sriwijaya pada awal abad ke-9 kemudian dijajah lagi oleh Majapahit. Setelah Majapahit runtuh, Brunei berdiri sendiri, bahkan pernah menguasai seluruh pulau Kalimantan dan Filipina. Kejayaan ini dicapai pada masa pemerintahan Sultan kelima Bolkiah yang berkuasa pada tahun 1473 sampai 1521.8 Pada masa berikutnya, datanglah orang Eropa di wilayah ini, dan Inggris sebagai negara kuat saat itu akhirnya menjadikan Brunei sebagai negara jajahan. Sejak tahun 1888, kerajaan Brunei termasuk negara persemakmuran Inggris. ${ }^{9}$ Pada saat yang bersamaan Malaysia juga dikuasai oleh Inggris. Penduduk kedua negara tersebut kemudian bersatu 
mengadakan perlawanan dan dalam rentang sejarah yang panjang kedua negara tersebut merdeka. Malaysia memproklamirkan diri sebagai negara merdeka pada tanggal 31 Agustus 1957, dan ketika itu Brunei masih dinyatakan bergabung dengan Malaysia. Setelah kemerdekaannya keadaan Malaysia belum begitu stabil terutama pada tahun 1960-an karena orangorang China sering konflik dengan masyarakat Melayu. ${ }^{10}$ Malaysia dan Brunei yang berpenduduk rumpun Melayu berusaha keras mengamankan negaranya, dan setelah betul-betul aman barulah Brunei memisahkan diri dari Malaysia.

PM Syarifuddin sebagaimana yang dikutip oleh Ajid Thohir mengatakan dalam tulisannya yang sangat menarik bahwa Brunei (lima abad lalu) yang mukim di Jerudong disebut orang Kedayan, berasal dari Jawa. Leluhur mereka tiba di Brunei di masa daulat Sultan Bolkiah. Inilah suku yang pertama tinggal di Brunei. ${ }^{11}$

Sebagian pengamat mengatakan sistuasi politik di Brunei tampaknya sangat tenang. Jumlah penduduknya 227.000 jiwa dengan kaum muslim sebagai kelompok mayoritas, Melayu 155.000 jiwa, China pendatang 41.000, masyarakat campuran 11.500 jiwa dan 20.000 dari Eropa dan pekerja dari Asia sekitarnya yang berasal dari Filipina. Namun data terakhir didapatkan bahwa jumlah penduduk Brunei adalah 370 ribu orang, $67 \%$ di antaranya beragama Islam dengan pendapatan berkapita sekitar US \$ 23.600 atau sekitar 225 juta rupiah. ${ }^{12}$ Sumber kekayaan utama yang dihasilkan Brunei adalah minyak mentah dan gas alam cair yang begitu melimpah. Tanahnya subur sehingga tanaman seperti karet, merica, dan rempah-rempah lainya merupakan hasil pertanian yang cukup menjanjikan. Ibu kota Brunei adalah Bandar Seri Begawan dan kepala pemerintahannya adalah seorang raja.

\section{MASUK DAN BERKEMBANGNYA ISLAM DI BRUNEI DARUSSALAM}

Sebagian sejarawan berbeda pendapat tentang sejarah awal masuknya Islam di Brunei Darussalam. Azyumardi Azra menulis bahwa sejak tahun 977 H. kerajaan Borneo (Brunei) telah mengutus P'u Ali ke Istana China. P'u Ali yang dimaksud adalah pedagang muslim yang nama sebenarnya adalah Abu 'Ali. Pada tahun yang sama, diutus lagi tiga duta ke Istana Sung, salah seorang di antaranya bernama Abu Abdullah.13

Versi lain mengatakan bahwa sekitar abad ke-7 pedagang Arab yang sekaligus sebagai pendakwah penyebar Islam telah datang ke Brunei. Kedatangan Islam di Brunei melegitimasikan bagi rakyat Brunei untuk menikmati Islam yang tersusun dari adat. Maksudnya, adat dan atau 
tradisi yang telah menjadi anutan masyarakat tetap dijalankan selama dapat memperkaya khzanah keislaman.

Berbeda dengan dua versi di atas, dalam Ensiklopedi Oxford dikemukakan bahwa orang Melayu Brunei menerima Islam pada abad ke- 14 atau ke-15 setelah pemimpin mereka diangkat manjadi Sultan Johor. ${ }^{14}$

Dari keterangan di atas didapatkan paling tidak ada tiga versi awal mula masuknya Islam di Brunei Darussalam yang tentunya memiliki alasan dan bukti yang kuat dalam menentukan masuknya Islam di negara tersebut. Hal ini menunjukkan bahwa bukan hanya di Indonesia didapatkan beberapa versi tentang masuknya Islam tetapi juga Brunei. Untuk sementara dapat disimpulkan bahwa kemungkinan besar semua negara Asean dan khususnya negara serumpun Melayu terdapat versi yang berbeda tentang waktu yang pasti masuknya Islam di wilayah tersebut.

Diduga kuat pula bahwa Islam masuk ke Brunei dengan pola top down. Maksudnya penerimaan Islam dimulai dari masyarakat elit, penguasa kerajaan, kemudian disosialisasikan dan berkembang ke masyarakat bawah. Di samping top down, juga ada yang disebut botton up, yakni Islam diterima terlebih dahulu oleh masyarakat lapisan bawah, kemudian berkembang dan diterima oleh masyarakat lapisan atas, atau elite penguasa kerajaan. ${ }^{15}$

Dengan pola top down ini, maka agama Islam dapat dengan cepat berkembang karena Islam terlebih dahulu telah dianut oleh raja. Raja bagi rakyat adalah penguasa yang harus ditaati. Dengan polapola itu, Islam memungkinkan lebih cepat diterima dan berkembang. Pola ini juga terjadi dalam penerimaan Islam di Nusantara sehingga Islam dengan begitu cepat diterima oleh masyarakat saat itu.

P.O.K Aman Diraja Dato Sri Utama mengatakan bahwa Brunei mengalami proses islamisasi ketika kerajaannya telah berdiri tidak jauh berbeda dengan Pattani atau Malaka. Tidak saja melihat ke pedalaman, tetapi juga seberang lautan, dalam menjalankan peranannya sebagai "jembatan penyeberangan" Islam. Keluarga kerajaan Brunei mendirikan suatu organisasi kekuasaan supredesa di Teluk Manila (Luzon). "Kesultanan" yang baru pada tahap pertumbuhan inilah yang dihadapi oleh Spanyol ketika mereka mendarat di Manila pada tahun $1570 .{ }^{16}$

Sebagai agama resmi negara, Islam mendapatkan dukungan yang sangat kuat dari penguasa dalam hal pihak kerajaan. Dominasi keluarga kerajaan di bidang pemerintahan memungkinkan pemerintah memberlakukan kebijakan di bidang agama dan umum lainnya tanpa banyak hambatan. Dan seperti dikatakan sebelumnya bahwa Brunei sangat berhati-hati terhadap pengaruh dari dunia luar, dan kekuasaan penuh ada pada raja 
sehingga kondisi sebagai masyarakat feodal tradisional ini akan tetap bertahan.

Meskipun sejak akhir abad akhir abad ke-19 sampai abad ke-20, terlihat perkembangan kehidupan keagamaan pada masyarakat Brunei yang sangat signifikan, baik pada tingkat kelembagaan maupun penerapan konsep-konsep reformasi. Tetapi status dan institusi-institusi Islam di Brunei tetap mencerminkan tradisi yang umumnya juga menjadi tradisi kesultanan di Semenanjung Melayu. Dalam kurun abad tersebut tidak tampak adanya gerakan atau peristiwa penting yang dapat merongrong agama. Brunei tidak tersentuh kontravesrsi keagamaan yang kadangkadang terjadi di kawasan ini. Ketika Inggris datang pada masa itu, sebagian masyarakat Islam Brunei menghormati Inggris sebagai penyelamat negara mereka. ${ }^{17} \mathrm{Di}$ sinlah kelihatan keunikan kehidupan beragama di Brunei dan Islam berkembang tanpa hambatan yang berarti. Masyarakat sangat taat kepada Raja dan paham keagamaanpun negara yang menentukan yaitu mazhab Syafi'i dalam urusan fikih dan berhaluan Ahlussunnah wal Jama'ah dalam bidang akidah. Paham lain bisa dipelajari tetapi itu hanya sebatas kajian saja. Bahkan pada suatu kesempatan pada perayaan Isra' Mi'raj tahun 1991 Sultan mengeluarkan dekrit yang isinya melarang pergerakan Al-Arqam. ${ }^{18}$ Paduka Yang Mulia selanjutnya memerintahkan kepada pihak pemerintah untuk melarang orang asing manapun yang dapat menjadi ancaman terhadap keharmonisan kehidupan beragama di Brunei.

Brunei merupakan salah satu negara yang sangat mempertahankan nilai-nilai bangsa Melayu. Hal tersebut dapat dilihat ketika Sri Baginda Sultan Haji Hassanal Bolkiah Mu'izzaddin Waddaulah, sangat menekankan pentingnya MIB (Melayu Islam Beraja, atau Kerajaan Islam Melayu). Menurutnya, interpretasi MIB harus menegaskan Brunei Darussalam" identitas dan citra yang kokoh di tengah-tengah negara-negara non sekuler lainnya di dunia, ${ }^{20}$ tetap mempertahankan nilai-nilai Islam-Melayu.

Perkembangan Islam di Brunei dapat dilihat dari segi kuatitas umat Islam itu sendiri. Seperti telah dijelaskan sebelumnya bahwa penduduk Brunei pada tahun 1988 adalah 227.000 jiwa dengan ras atau suku Melayu, China, Eropah dan pekerja asing lainnya. Penduduk Brunei senantiasa berkembang dari segi kuantitas sehingga penduduk Brunei tahun 1991 telah menjadi 397.000 jiwa dengan masyarakat muslim 64\%, Budha $14 \%$, dan Kristen 10\%. Data terakhir tahun 2004 jumlah penduduh Brunei telah mencapai 443.653 jiwa. ${ }^{21}$ Meskipun demikian, penduduk muslim masih tetap sebagai kelompok mayoritas. 
Islam di Brunei senantiasa mengalami perkembangan di antara negara-negara Muslim lainnya, khususnya di Asia Tenggara. Hal ini dapat dilihat dengan partisifasi Brunei dalam forum-forum umat Islam. Bahkan menjadi penyelenggara berbagai forum Islam regional dan Internasional. Hal ini dapat dilihat ketika menjadi tuan rumah bagi pertemuan Komite Eksekutif Dewan Dakwah Islam Asia Tenggara dan Fasik (Regional Islamic Council of South East Asia and Fasific, RISEP). Sultan Hasanah Bolkiah pernah menghadiri perayaan yang menandai pembukaan Festifal Budaya Islam di Jakarta dan menghadiri Konfrensi Islam OKI yang diselenggarakan di Qatar. Posisi sentral Islam lagi-lagi diperkuat di bulan September 1992 dengan didirikannya Tabung Amanah Islam Brunei (TAIB) atau Dana Amanah Umat Islam Brunei, lembaga finansial pertama di Brunei yang dijalankan berdasarkan Syariat Islam. ${ }^{22}$ Tujuan lembaga keuangan tersebut adalah untuk membantu investasi di bidang bursa dan pasang uang, berpartisifasi dalam pembangunan ekonomi dan industri baik di dalam maupun luar negeri, dan menjalankan fungsi-fungsi lainnya yang diatur secara terbuka.

Ada satu hal sangat luar biasa yang menunjukkan betapa besar perhatian kerajaan kepada rakyatnya. Paduka ketika membuka acara perayaan nuzul al-Qur'an (diturunkannya al-Qur'an), sultan menekankan bahwa pemerintah mengatur kebijakan dan berkeinginan agar semua warga negara Brunei mampu membaca al-Qur'an. ${ }^{23}$ Kebijakan tersebut kemudian diperkuat dengan maklumat bahwa Brunei telah menghabiskan dana lebih dari BS 2 juta untuk menerbitkan sejumlah al-Qur'an tulisan tangan yang ditulis oleh komisi khusus. Sebuah perusahaan Mesir akan menerbitkan 150.000 eksemplar untuk didistribusikan ke sekolah-sekolah di Kesultanan Brunei dan untuk para pengunjung tertentu dari negaranegara Islam. Sultan menekankan pentingnya pengajaran bahasa Melayu dalam aksara Jawi (berdasarkan alfabet Arab) dan juga aksara Rumi (berdasarkan alfabet Latin). Penekanan baru ini akan semakin memperkuat hubungan antara negara serumpun Melayu dengan warisan budaya Islam.

Dari keterangan yang dipaparkan di atas tampak betapa besarnya perhatian kerajaan terhadap aktifitas-aktifitas ini yang dapat dipahami sebagai bentuk dukungan sangat serius dari pihak kerajaan terhadap proses islamisasi demi kemajuan Islam di Brunei dan juga kepada negara serumpun yaitu Melayu.

\section{PERKEMBANGAN PENDIDIKAN ISLAM DI BRUNEI DARUSSALAM}

Pendidikan adalah proses perubahan sikap dan tata laku seseorang atau kelompok orang dalam usaha mendewasakan menusia melalui upaya 
pengajaran dan pelatihan: proses, perbuatan, cara mendidik. ${ }^{24}$ Pendidikan juga disebut sebagai sistem training dan pengajaran yang didesain untuk memberi pengetahuan dan keterampilan. ${ }^{25}$ Pendidikan bukan hanya suatu upaya yang melahirkan proses pembelajaran yang bermaksud membawa manusia menjadi sosok yang potensial secara intelektual melalui transfer of knowledge yang kental, tetapi proses tersebut bermuara kepada upaya pembentukan masyarakat yang berwatak, beretika, dan estetika serta bermoral. Pendidikan Islam menurut Razalinda Under adalah satu usaha untuk mengembangkan fitrah manusia sesuai dengan ajaran agama Islam berlandaskan al-Qur'an dan al-Sunnah yang akhirnya akan mewujudkan satu masyarakat yang bertamaddun tinggi, penuh rahmat dan kebahagiaan serta mendapat keredaan Allah. ${ }^{26}$ Pendidikan Islam berusaha untuk mengembangkan semua aspek dalam kehidupan manusia. Aspek-aspek tersebut meliputi antara lain, spritual, intelektual, imajinasi, keilmiahan, dan lain sebagainya. ${ }^{27}$ Dengan demikian, pendidikan bertujuan untuk memadukan paling tidak tiga aspek pada diri manusia yaitu: aspek intelektual, spritual, dan emosional.

Term yang diidentikkan dengan istilah pendidikan adalah pengembangan sumber daya manusia. Kemajuan suatu bangsa terkadang diukur dengan kualitas sumber daya manusianya. Oleh karena itu, hampir semua negara berusaha secara maksimal untuk meningkatkan sumber daya manusianya. ${ }^{2}$

Brunei Darussalam sebagai sebuah negara sudah barang tentu akan memperhatikan sumber manusianya. Hal ini selalu ditekankan oleh para menteri kabinet dalam setiap pidatonya tentang tantangan mengelola perubahan dalam konteks pembangunan nasional. ${ }^{28}$ Oleh karena itu, pemerintah Brunei meningkatkan pengelolaan sumber daya manusia yang menurutnya terletak pada pelatihan generasi muda. Bahasa Melayu dan Inggris memiliki penekanan yang sama. Pada pendidikan dasar pelajaran diajarkan dalam bahasa Inggris. Penekanan pada bahasa Inggris ini diimbangi dengan pengajaran MIB (Melayu Islam Beraja atau Kerajaan Islam Melayu) seperti ajaran agama Islam, yang merupakan program pengajaran moral inti di sekolah. Pelajaran satu tahun dalam bidang MIB terutama diwajibkan untuk mahasiswa. Sekolah-sekolah sekunder bahasa Arab juga dibangun pada tahun 1970, dan bagi siswa yang memenuhi syarat kemudian dikirim ke Al-Azhar University di Kairo. Brunei Religious Teachers College (sekolah Guru Agama Brunei) yang didirikan pada tahun 1972 melatih dan mempersiapkan guru-guru agama. ${ }^{29}$

Universitas Brunei Darussalam menyelenggarakan pertemuan ketiganya pada tahun 1991, dan menelorkan 200 lulusannya. Sejak didirikan 
tahun 1985, lembaga ini telah meluluskan 500 sarjana. Pada tahun 1991 telah melakukan MoU dengan University Technologi Malaysia untuk memperkuat kerjasama dalam bidang pendidikan dan penelitian. ${ }^{30}$

Pendidikan formal di Brunei dimulai tahun 1912 dengan mulai dibukanya Sekolah Melayu di Bandar Brunei (Bandar Sri Begawan sekarang). Kemudian diikuti dengan pembukaan sekolah lain tahun 1918 di wilayah Brunei-Muara, Kuala Belait dan Tutong khusus untuk murid laki-laki berusia 7-14 tahun dengan kurikulum pelajaran mencakup membaca dan menulis dalam bahasa Arab dan Latin. Sebelumnya, tahun 1916, masyarakat Tionghoa telah mendirikan sekolah sendiri di Bandar Sri Begawan. Baru pada tahun 1913 Sekolah Dasar Swasta pertama berbahasa Inggris berdiri di Seria. Sampai dengan tahun 1941, jumlah sekolah di Brunei mencapai 32 buah yang terdiri dari 24 sekolah Melayu, 3 sekolah swasta Inggris, 5 sekolah China dengan jumlah murid 1.714 orang dan 312 orang murid wanita. 31

Pada tahun 1966 sekolah Melayu pada tingkat pendidikan menengah dibuka di Belait. Tahun 1984 kurikulum pendidikan nasional mewajibkan para peserta didik untuk menguasai dwibahasa yaitu bahasa Melayu dan bahasa Inggris. Puncaknya berupa berdirinya Universiti Brunei Darussalam tahun 1985 sebagai lembaga tertinggi di bidang pendidikan.

Prioritas utama pemerintah kerajaan Brunei dalam pendidikan adalah menuju arah kemajuan pembangunan dan pengembangan sumber daya manusia di ero globalisasi, peningktan sektor pendidikan termasuk pendidikan teknik dan kejuruan di mana kurikulumnya selalu ditinjau ulang. Program pendidikan diarahkan untuk menciptakan manusia yang berakhlak dan beragama serta menguasai teknologi. Pemerintah telah menetapkan tiga bidang utama dalam pendidikan yaitu: Sistem dwi bahasa di semua sekolah, Konsep melayu Beraja (MIB) dalam kurikulum sekolah dan peningkatan serta perkembangan sumber daya manusia termasuk pendidikan vokasional (kejuruan).

Sistem pendidikan di Brunei memiliki banyak kesamaaan dengan negara lainnya seperti Inggris, Malaysia, Singapura dan lain-lain. Sistem ini dikenal dengan pola A7-3-2-2 yang melambangkan lamanya masa studi untuk masing-masing tingkatan seperti: 7 tahun tingkat dasar, 3 tahun tingkat menengah pertama, 2 tahun tingkat atas dan 2 tahun prauniversitas. Pemerintah mengutamakan penciptaan sumber daya manusia yang berakhlak, beragama, dan menguasai teknologi. ${ }^{32}$

Sistem pendidkan Islam telah mengalami perubahan yang pada awalnya dilakukan secara pribadi oleh para ulama melalui lembaga yang mereka miliki yang lebih bersifat tidak resmi atau informal. Pendidikan 
Islam bagi orang Brunei ditujukan kepada semua lapisan masyarakat tidak hanya untuk satu-satu kelompok masyarkat. Pendidikan tidak boleh hanya berpusat di istana atau di kediaman golongan elite, tetapi kini juga bertempat di masjid-masjid, atau surau-surau, balai-balai ibadat, pondokpondok pengajian agama Islam tidak terkecuali juga di rumah guru-guru agama. Kampong Air merupakan pusat pelajaran agama.

Pada tahun 1950-an pendidikan Islam belum memiliki kurikulum tersendiri dan tidak terikat dengan waktu. Pengajian hanya bersifat perorangan, tenaga pengajar hanya menerima ehsan dan pemberian sukarela dari pelajarnya, serta pelajar-pelajarnya masih didominasi kaum lelaki. Namun, sekarang pendidikan agama lebih sistimatik, guru-guru agama harus ditatar di sekolah agama yang dikenal. Pendidkan agama Islam juga menjadi salah satu mata pelajaran yang diterapkan di seluruh sekolah. Ajaran Islam merupakan program pengajaran moral inti sekolah-sekolah di Brunei, tanpa mengabaikan pelajaran lain termasuk bahasa Inggris tetap menjadi penekanan.

Pemerintah Brunei senantiasa berusaha keras untuk memulihkan nafas keislaman dalam suasana politik yang baru. Di antara langkahlangkah yang diambil adalah mendirikan lembaga-lembaga moderen yang selaras dengan tuntutan Islam. Di samping menerapkan hukum syariah dalam pandangan negara. Didirikan pula Pusat Kajian Islam serta Lembaga Keuangan Islam.

Dalam kaitan ini Dr. Haji Awang Asbol Bin Haji Mail mengatakan:

Di Brunei kerajaan memainkan peranan penting. Dia bada satu pusat dakwah, kita mencoba menerapkan falsafah Islam Melayu kerajaan, memang selaras dengan Islam memang sudah dibuat kemudian disambung lagi oleh Sultan Hassanal Bolkiah, malah setiap keramaian Islam, pegawai-pegawai pekerjaan di wajibkan datang, dijemput seperti maulid Nabi. ${ }^{33}$

Meskipun demikian langkah mengembangkan Islam dalam sendisendi masyarakat tetap berjalan. Prof. Lik Arifin Mansur Nurdin, dosen di Universitas Brunei Darussalam memastikan bahwa peserta didik yang belajar di Pusat Kajian Islam di sana berinteraksi satu sama lain dengan mahasiswa dari fakultas lain, sehingga mereka mendapatkan pandangan yang komprehensif. Di Universitas Brunei Darussalam ada Faculty of Islamic Studies. Di fakultas ini ada interaksi antara Islamic Studies dengan disiplin lain. Jadi, selain mengerti sains juga mengerti apa prinsip-prinsip Islam tentang sains. Hal ini dianggap sebagai satu diskursus yang baik bukan dipaksakan.

Selanjutnya diuraikan perkembangan sekolah di Brunei. Sekolah menengah agama Islam Shamsuddiniah, merupakan sebuah sekolah mene- 
ngah agama. Sekolah ini terletak di Kampung Parit Medan, Kundang Ulu, Muar. Tempatnya yang jauh dari kesibukan bandar ini memberikan satu keistimewaan kepada sekolah ini, di mana ia sering menjadi pilihan ibu bapak yang mau memberikan anak-anak mereka didikan agama yang sempurna di samping untuk mengelakkan mereka dari gejala sosial yang kian meruncing dewasa ini. ${ }^{34}$

Kalau ditelusuri ke belakang sejak dekade awal penjajahan Inggris, akan kelihatan bahwa kebanyakan masyarakat Islam mendapatkan pendidikan secara tidak formal sebagaimana telah dikemukakan sebelumnya. Anak mendapatkan pendidikan dari para ulama ketika itu, untuk memenuhi tuntutan agama. Agar setiap umatnya dapat menuntut ilmu agama, didirikanlah Madrasah Shamsuddiniah Assalafiah pada tahun 1940, setelah mendapat izin Jabatan Agama Islam Johor (JAIJ) pada 12 Mei tahun yang sama. ${ }^{35}$

Seperti umunya madrasah di negara lain, pelajaran yang diajarkan di Madrasah Shamsuddiniah adalah tauhid, fikih, hadis, nahu, saraf dan lainlain. Menjelang tahun 1956, meskipun fasilitas seadanya sekolah ini diminati oleh masyarakat. Madrasah ini juga melakukan perubahan kurikulum mengikuti sistem pendidikan yang dipergunakan oleh sekolahsekolah Arab negeri Johor ketika itu. Dengan pemberlakuan kurikulum tersebut maka Madrasah Shamsuddiniah didaftarkan sebagai Sekolah Menengah Agama (Rendah) negeri Johor. Di Jabatan Agama Johor madrasah ini didaftarkan di bawah JAIJ untuk menentukan kedudukannya sebagai institusi yang sah.

Memperhatikan perkembangan madrasah sebagai sebuah institusi pendidikan yang baru dikenali, madrasah ini pada awalnya hanya mempunyai satu bangunan sekolah yang mampu menempatkan lebih dari 50 orang pelajar laki-laki ${ }^{36}$ dalam suasana yang terbatas

Sistem pendidikan yang berorientasikan pondok ini senantiasa melaksanakan pendidikan meskipun kondisinya masih sangat kekurangan, tetapi demikian semangat para peserta didik tetap menikmati kondisi ini dengan keadaan seperti ini mereka dapat menguasai bahasa Arab dengan baik ditambah dengan penggunaan bahasa Inggris dan bahasa Melayu sebagai medium komunikasi.

\section{PENUTUP}

Setelah diuraikan sejarah masuknya Islam di Brunei dan perkembangan pendidikannya, maka dapat disimpulkan sebagai berikut:

Pertama, Islam berkembang di Brunei dengan baik dan cepat. Hal ini disebabkan karena pola penyebaran Islam di sana memakai pola top down. 
Karena penguasa atau raja telah lebih dahulu memeluk agama Islam, maka rakyat pun mudah mengikuti pemempin mereka karena raja sangat dihormati oleh rakyatnya. Namun, pola ini dapat berdampak negatif terhadap penerimaan ajaran suatu agama karena ada unsur keterpaksaan rakyat untuk menerimanya. Sebaliknya pola button up masyarakat lebih bebas sesuai keyakinan. Kemajuan Islam dibuktikan dengan dikelurkannya dana yang sangat mamadai untuk mendukung syiar agama dan partisipasi kerajaan dalam perayaan hari-hari besar Islam.

Kedua, perkembangan dan kemajuan Islam dan Pendidikan Islam di Brunei mengalami kemajuan yang sangat mengembirakan. Hal ini dapat dilihat di mana para siswa bermula belajar agama dari para ulama secara perorangan atau informal, kemudian melanjutkan ke madrasah yang diambil alih oleh pemerintah dalam pengelolaannya. Lembaga pendidikan di Brunei melakukan pengintegrasian ilmu pengetahuan agama dengan sains sehingga peserta didik memahami prinsip-prinsip agama sekaligus menguasai sains.

\section{CATATAN AKHIR:}

1. Azyumardi Azra, Islam di Asia Tenggara, Pengantar Pemikiran dalam Azyumardi Azra (Ed.), Perspektif Islam di Asia Tenggara (Jakarta:Yayasan Obor, 1989), h.VI-VIII.

2. Awang Sariyan, Penghayatan dan Peningkatan Ilmu dalam Pelbagai Bidang Melalui Bahasa Kebangsaan: Cabaran dalam Dunia Pendidikan Masa Kini dan Masa Hadapan, sumber data.

3. Che Ude Che Nik, Sejarah Islam 2 (Cet. II; Selangor Malaysia: Fajar Bakti Sdn Bha, 1981), h.102.

4. Sharon Siddiqi, BruneiDarussalam: Sebuah Bangsa Religius yang Potensial dalam Muflich Hasbullah, ed. Asia Tenggara Konsentrasi Baru Kebangkitan Islam (Cet. II; Bandung: Fokusmedia, 2005), h. 246.

5. Lihat http:/id.wikipedia.org/wiki/Brunei Darussalam dicopy tgl 15 Oktober 2008.

6. Abdul Hadi Muthohhar, Pengaruh Mazhab Syafi'i di Asia Tenggara (Cet. I; Semarang: Aneka Ilmu, 2003), h.101. Dikutip dari sumber: Pehin Orang Kaya Ratna Dato Seri Utama Dr. Haji Md Zain bin Haji Serudin, "Suatu Pendekatan Mengenai Islam di Brunei Darussalam" dalam Seminar Studi Islam Asia Tenggara (Surakarta: mommiogaraph UMS, 19-21 Maret 1990), h.31.

7. Abdul Hadi Muthohhar, Pengaruh Mazhab Syafi'i di Asia Tenggara (Cet. I; Semarang: Aneka Ilmu, 2003), h. 101.

8. Lihat http://id.wikipedia.org/wiki/Brunei Darussalam dicopy 10 Sept 2008.

9. Ajid Thohir, Perkembanagan Peradaban Islam di Kawasan Dunia Islam (Cet.I; Jakarta: Raja Grafindo Persada, 2002), h. 262.

10. Lihat hhtp:www.ai-shia.com/htm/id/service/info-Negara-Muslim/Malaysia. $\mathrm{htm}$. dicopy 10 Oktober 2008. 
11. Ajid Thohir, Perekembangan Peradaban di Kawasan Dunia Islam, Melacak Akar-akar Sejarah, Sosial, Politik, dan Budaya Umat Islam, (Cet. I; Jakarta: 2004), h. 262.

12. www.melayuonline-com.

13. Azyumardi Azra, Jaringan Ulama Timur Tengah dan Nusantara Abad XVII dan XVIII (Cet. II; Jakarta:......2005), h. 29-30.

14. Lihat Jejak Rasul 10 Pedagang Arab sebarkan Islam ke Brunei dalam http://www.bharian.com.my.misc/Ramadhan Almubarak/jejakrasul/200411 05112413/articles

14. John L. Esposito (ed) The Oxford Encyclopedia of the Modern Islamic World, Vol 3 (Oxford University Press, 1995), h. 299.

15. Ahmad M. Sewang, Islamisasi Kerajaan Gowa (Cet. II; Jakaarta: Yayasan Obor, 2005), h. 86.

16. P.O.K. Aman Diraja Daso Seri Utama (dr) Hadji Mohammad Jamil Al-Sufri, Islam in Brunei dalam Taufik Abdullah, Tradisi dan Kebangkitan Islam di Asia Tenggara, (Cet. I; Jakarta: LP3ES, 1989), h. 72.

17. John L. Esposito, The Oxford Encyclopedia of the Modern Islamic World, h. 299.

18. Organisasi Islam Fundamentalis, Darul Arqam, yang markasnya di Subur Kuala Lumpur, pada mulanya dilarang di negeri asalnya, Malaysia.

19. Sharon Siddique, BruneiDarussalam: Sebuah Bangsa Religius yang Potensial, h. 246.

21. http/id.wikipedia.org.wiki/Brunei-darussalam.

22. Sharon Shiddique, BruneiDarussalam: Sebuah Bangsa Religius yang Potensial, h. 249

23. Sharon Shiddique, BruneiDarussalam: Sebuah Bangsa Religius yang Potensial, h. 249

24 Tim Penyusun Kamus Pusat Pembinaan dan Pengembangan Bahasa, Kamus Besar Bahasa Indonesia, Ed. II (Cet. IV; Jakarta: Balai Pustaka, 1995), h. 232.

24. Lihat A.S. Hornby, Oxford Advanced Leaner's Dictionary of Current English Ed. IV (Oxford: Oxford University Press, 1989), h. 385.

25. Razalinda Under Makalah hal. 5.

26. Aden Wijdan Z, Pendidikan Islam dalam Peradaban Industrial (Cet. I; Yogyakarta: Adtya Media, 1997), h.10.

27. Sharon Shiddique, BruneiDarussalam: Sebuah Bangsa Religius yang Potensial, h. 256.

28. Sharon Shiddique, BruneiDarussalam, h. 256.

29 www.indonesia.org.id.

30 www.indonesia.org.id

31. www.melayuonline-com ibd.

32. www.melayuonline-com ibd.

33. www.melayuonline-com ibd.

34. http://www.pij.gov.my/smas/sejarah.html.

35. http://www.pij.gov.my/smas/sejarah.html.

36. http://www.pij.gov.my/smas/sejarah.html. 


\section{DAFTAR PUSTAKA:}

Al-Sufri, P.O.K. Aman Diraja Dato Seri Utama (dr) Hadji Mohammad Jamil. Islam in Brunei dalam Taufik Abdullah, Tradisi dan Kebangkitan Islam di Asia Tenggara, Cet. I; Jakarta: LP3ES, 1989.

Azra, Azyumardi. Islam di Asia Tenggara, Pengantar Pemikiran dalam Azyumardi Azra (Ed.), Perspektif Islam di Asia Tenggara, Jakarta:Yayasan Obor, 1989.

Azra, Azyumardi. Jaringan Ulama Timur Tengah dan Nusantara Abad XVII dan XVIII, Cet. II; Jakarta:......2005.

Che Nik, Che Ude. Sejarah Islam 2, Cet. II; Selangor Malaysia: Fajar Bakti Sdn Bha, 1981.

Esposito, John L. (ed). The Oxford Encyclopedia of the Modern Islamic World, Vol 3, Oxford University Press, 1995.

hhtp:www.ai-shia.com/htm/id/service/info-Negara-Muslim/Malaysia.htm.

Hornby, A.S. Oxford Advanced Leaner's Dictionary of Current English Ed. IV, Oxford: Oxford University Press, 1989.

http://id.wikipedia.org/wiki/Brunei Darussalam.

http://www.bharian.com.my.misc/Ramadhan Jejak Rasul 10 Pedagang Arab sebarkan Islam ke Brunei.

http://www.pij.gov.my/smas/sejarah.html.

http:/id.wikipedia.org/wiki/Brunei Darussalam

Muthohhar, Abdul Hadi. Pengaruh Mazhab Syafi'i di Asia Tenggara, Cet. I; Semarang: Aneka Ilmu, 2003.

Sariyan, Awang. Penghayatan dan Peningkatan Ilmu dalam Pelbagai Bidang Melalui Bahasa Kebangsaan.

Serudin, Haji Md Zain bin Haji. "Suatu Pendekatan Mengenai Islam di Brunei Darussalam" dalam Seminar Studi Islam Asia Tenggara, Surakarta: mommiogaraph UMS.

Sewang, Ahmad M. Islamisasi Kerajaan Gowa. Cet. II; Jakaarta: Yayasan Obor, 2005.

Siddiqi, Sharon. BruneiDarussalam: Sebuah Bangsa Religius yang Potensial dalam Muflich Hasbullah, ed. Asia Tenggara Konsentrasi Baru Kebangkitan Islam, Cet. II; Bandung: Fokusmedia, 2005.

Thohir, Ajid. Perekembangan Peradaban di Kawasan Dunia Islam, Melacak Akar-akar Sejarah, Sosial, Politik, dan Budaya Umat Islam, Cet. I; Jakarta: 2004.

Thohir, Ajid. Perkembanagan Peradaban Islam di Kawasan Dunia Islam, Cet.I; Jakarta: Raja Grafindo Persada, 2002.

Tim Penyusun Kamus Pusat Pembinaan dan Pengembangan Bahasa, Kamus Besar Bahasa Indonesia, Ed. II, Cet. IV; Jakarta: Balai Pustaka, 1995.

Wijdan Z, Aden. Pendidikan Islam dalam Peradaban Industrial, Cet. I; Yogyakarta: Adtya Media, 1997.

www.indonesia.org.id.

www.melayuonline-com. 